\title{
STUDIES ON BIOSYNTHESIS OF KASUGAMYCIN. I
}

\author{
BIOSYNTHESIS OF KASUGAMYCIN AND THE KASUGAMINE MOIETY
}

\author{
Yasuo Fukagawa, Tsutomu Sawa, \\ Tomo Takeuchi and Hamao Umezawa
}

Institute of Microbial Chemistry

(Received for publication July 24, 1967)

\begin{abstract}
Incorporation of $\mathrm{U}^{-14} \mathrm{C}-$ glucose, $\quad \mathrm{U}^{14} \mathrm{C}$-maltose, $\mathrm{U}-{ }^{14} \mathrm{C}$-mannose, $\mathrm{U}-{ }^{14} \mathrm{C}-$

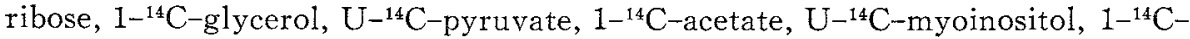
glycine, $2{ }^{-14} \mathrm{C}-$ glycine and $\mathrm{U}-{ }^{14} \mathrm{C}-$ glycine into kasugamycin and its kasugamine moiety was reported. The incorporation of $\mathrm{U}-{ }^{14} \mathrm{C}-\mathrm{glucose}$ and $\mathrm{U}-{ }^{14} \mathrm{C}$-mannose into kasugamycin was 5 -fold that of $\mathrm{U}^{-14} \mathrm{C}$-maltose. $\mathrm{U}-{ }^{14} \mathrm{C}-$ glucose, $\mathrm{U}^{14} \mathrm{C}-$ mannose and $\mathrm{U}-{ }^{14} \mathrm{C}$-maltose were incorporated into the kasugamine moiety more than into the other moieties. $\mathrm{U}-{ }^{14} \mathrm{C}-\mathrm{M}$ yoinositol, $1{ }^{14} \mathrm{C}-$ glycine and ${ }^{2-14} \mathrm{C}$-glycine were incorporated into kasugamycin mostly in the parts other than kasugamine.
\end{abstract}

The structure of kasugamycin, including stereochemistry, has been determined by chemical studies ${ }^{1 \sim 5}$ and $\mathrm{X}$-ray analysis of its hydrobromide ${ }^{6)}$. As shown by the structure, the kasugamycin molecule can be divided into three moieties, namely the iminoacetic acid side chain, 2,3,4,6-tetradeoxy-2,4-diaminohexopyranose or kasugamine, and D-inositol.

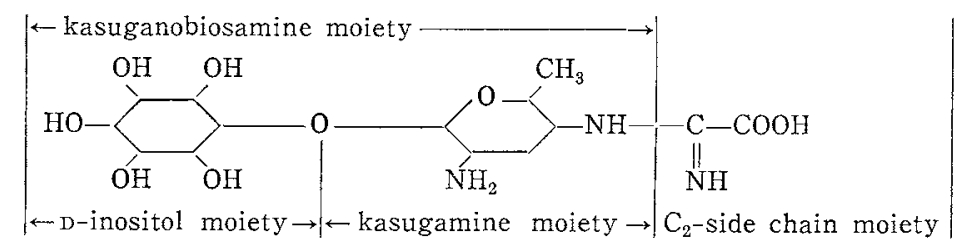

The structure of the side chain suggests that it may be biosynthesized from an amino acid, especially from glycine. The presence of $\mathrm{D}$-inositol suggests that it may be derived from myoinositol, which is also known to be an intermediate for streptidine $^{7)}$ or deoxystreptamine ${ }^{8)}$ from glucose. As will be reported ${ }^{0,10)}$, two carbons of glycine are incorporated into the side chain and myoinositol into D-inositol. In this paper, the incorporation of radioactive compounds into kasugamycin and the relative incorporation into the kasugamine moiety are reported.

\section{Methods and Materials}

1. Shaking culture of the kasugamycin-producing strain: A subculture of Streptomyces kasugaensis was maintained on a slant agar consisting of maltose $1.0 \%$, yeast extract (purchased from Oriental Yeast Co., Tokyo) $0.4 \%$, and agar $1.5 \%$ (pH 6.0). A loopful amount of the culture on the agar slant was inoculated into a $500 \mathrm{ml}$ flask containing $125 \mathrm{ml}$ of the following medium and shaken at $27^{\circ} \mathrm{C}$ on a reciprocal shaking machine (130 
strokes/minute with amplitude of $7.0 \mathrm{~cm}$ ). The composition of the medium was: maltose $1.5 \%$, soybean meal $1.5 \%, \mathrm{~K}_{2} \mathrm{HPO}_{4} 0.1 \%, \mathrm{NaCl} 0.3 \%$, and $\mathrm{MgSO}_{4} \cdot 7 \mathrm{H}_{2} \mathrm{O} 1.1 \%$ in distilled water.

2. Determination of kasugamycin and residual sugar during fermentation: Kasugamycin was determined by its antimicrobial activity against Piricularia oryzae or Pseudomonas fuorescens. The methods have been described by M. HAMAdA et al. ${ }^{11}$ The residual sugar was determined by the anthrone method. That is, $4 \mathrm{ml}$ of the anthrone reagent $\left(0.2 \mathrm{~g}\right.$ anthrone in $100 \mathrm{ml}$ of conc. $\left.\mathrm{H}_{2} \mathrm{SO}_{4}\right)$ was cooled to $0 \sim 10^{\circ} \mathrm{C}$ in ice water and $2 \mathrm{ml}$ of a sample which was estimated to contain $20 \sim 40 \mathrm{mcg} / \mathrm{ml}$ of sugar was layered carefully over the reagent. Under cooling, it was mixed and thereafter held at room temperature for about 30 minutes. Then, it was heated at $90^{\circ} \mathrm{C}$ for 16 minutes and cooled in ice water. The optical density at $625 \mathrm{~m} \mu$ was read. The standard curve of glucose was prepared and the amount of residual sugar was calculated from the standard curve of glucose.

3. Addition of labelled compounds: Labelled compounds were dissolved in $0.1 \sim$ $0.2 \mathrm{ml}$ of distilled water and added to the shaking-culture of $S$. kasugaensis, during the production phase, that is, at 70 90 hours' shaking culture. The shaking-culture was continued further for 15 24 hours.

4. Isolation of kasugamycin: The cultured broth was adjusted to $\mathrm{pH} 5.0$ with $1 \mathrm{~N}$ $\mathrm{HCl}$ and centrifuged for 15 minutes at 3,000 r.p.m. The supernatant solution $(120 \mathrm{ml})$ was passed through a column $(20 \mathrm{ml})$ of $\mathrm{XE}-100$ resin in $\mathrm{NH}_{4}{ }^{+}$form and the column was washed with distilled water $(100 \mathrm{ml})$. Thereafter, radioactive kasugamycin was eluted with $0.2 \mathrm{~N} \mathrm{NH}_{4} \mathrm{OH}$. The eluate which showed the inhibitory activity against Pyricularia oryzae and Pseudomonas fluorescens was neutralized with $1 \mathrm{~N} \mathrm{HCl}$ and, after concentration to $5.0 \mathrm{ml}$, adsorbed on a column $(5 \mathrm{ml})$ of active carbon at $\mathrm{pH} 8.5$. After the column was washed with $5 \mathrm{ml}$ of distilled water, kasugamycin was eluted with $0.05 \mathrm{~N} \mathrm{HCl}$. The eluate containing radioactive kasugamycin was neutralized with Dowex-3 $\left(\mathrm{OH}^{-}\right.$form) and about $200 \mathrm{mg}$ of kasugamycin was added. The kasugamycin solution was concentrated in vacuo to about $1.0 \mathrm{ml}$ (kasugamycin about $300 \mathrm{mg} / \mathrm{ml}$ ) and ethanol was added until a precipitate started to form. The solution was placed at $0 \sim 5^{\circ} \mathrm{C}$ overnight. Crystalline radioactive kasugamycin was separated and dried.

5. Degradation of kasugamycin: As reported by SuHARA et al. ${ }^{1)}$, reflux in $6 \mathrm{~N} \mathrm{HCl}$ gives $\mathrm{D}$-inositol but not kasugamine which further decomposes. Kasugamycin hydrochloride monohydrate $(100 \mathrm{mg})$ was dissolved in $1 \mathrm{ml}$ of distilled water and $3.0 \mathrm{ml}$ of saturated solution of $\mathrm{Ba}(\mathrm{OH})_{2}$ was added. Heating at $90 \sim 100^{\circ} \mathrm{C}$ for 8 hours yielded a precipitate. Dissolution of the precipitate in aqueous hydrochloric acid followed by neutralization with $\mathrm{Ba}(\mathrm{OH})_{2}$ solution gave barium oxalate $(55.9 \mathrm{mg})$ which originated from the two carbons in the side chain. The supernatant was neutralized by addition of dry ice and the barium carbonate precipitate was removed. The filtrate was passed through a column $(5 \mathrm{ml})$ of Amberlite $\mathrm{CG}-50$ in $\mathrm{NH}_{4}{ }^{+}$form and after distilled water $(25 \mathrm{ml})$ was passed, kasuganobiosamine was eluted with $0.1 \mathrm{~N} \mathrm{NH}_{4} \mathrm{OH}$. The eluate containing kasuganobiosamine was concentrated and dried (the theoretical yield is $70.8 \mathrm{mg}$ ).

As reported in a previous paper by SuHARA et al. ${ }^{2)}$, methanolysis of kasuganobiosamine gives $\beta$-methyl kasugaminide. However, this reaction is slow and the yield is very low. Therefore, the specific activity of kasugamine was calculated from the specific activity of kasuganobiosamine and $\mathrm{D}$-inositol as follows:

Specific activity of kasugamine $/ \mu \mathrm{M}=$ Specific activity of kasuganobiosamine/ $\mu \mathrm{M}-\mathrm{specific}$ activity of $\mathrm{D}$-inositol/ $\mu \mathrm{M}$

Kasugamycin was degraded to D-inositol by the following procedure: Crystals $(50 \mathrm{mg}$ ) of radioactive kasugamycin hydrochloride monohydrate was dissolved in $1 \mathrm{ml}$ of $6 \mathrm{~N} \mathrm{HlC}$ and heated in a sealed tube for 5 hours at $105 \sim 110^{\circ} \mathrm{C}$. The hydrolysate was concentrated and dried in a dessicator containing $\mathrm{NaOH}$. Cold D-inositol $(20 \mathrm{mg})$ was added and the 
mixture was dissolved in a small amount of distilled water. Ethanol (about $3 \mathrm{ml}$ ) was added and, after holding at $0 \sim 5^{\circ} \mathrm{C}$, crystals of radioactive $\mathrm{D}$-inositol were collected (the theoretical yield is $40.7 \mathrm{mg}$ ).

6. Measurement of radioactivity: The radioactivity was counted with a gas flow counter (Aloka $2 \pi$ Gas Flow Counter FC-1E; Dekatron Timer TDT-2; Automatic Readout Scaler TDT-9) of Japan Radiation \& Medical Electronics, Inc. or a liquid scintillation counter CPM-200 (LS-II) of Beckman Instruments, Inc. The scintillation medium used for radioactivity determination consisted of $4 \mathrm{~g}$ of PPO (2,5-diphenyloxazole), $0.2 \mathrm{~g}$ of dimethyl POPOP $\{1,4$-bis [2-(4-methyl-5-phenyloxazolyl] benzene $\}, 60 \mathrm{~g}$ of naphthalene, $100 \mathrm{ml}$ of methanol, $20 \mathrm{ml}$ of ethylene glycol and $880 \mathrm{ml}$ of dioxane. After the radioactive compounds were subjected to paper chromatography or high voltage electrophoresis, the chromatograms were scanned with a paper chromatogram scanner (PCS-2 with Ratemeter TRM-1 and Recorder ER-1-10-12) of Japan Radiation \& Medical Electronics, Inc.

7. Radioactive chemicals: $\mathrm{U}-{ }^{14} \mathrm{C}$-glucose, $1{ }^{14} \mathrm{C}$-acetate, $\mathrm{U}-{ }^{14} \mathrm{C}$-pyruvate and $\mathrm{U}-{ }^{14} \mathrm{C}-$

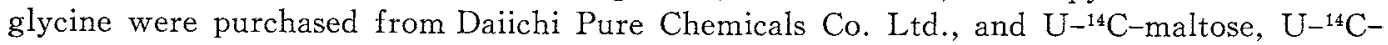
mannose, U- ${ }^{14} \mathrm{C}-$ ribose, $1-{ }^{14} \mathrm{C}-$ glycerol, $\mathrm{U}-{ }^{14} \mathrm{C}-$ myoinositol, $1{ }^{-{ }^{14}} \mathrm{C}-$ glycine, and $2-{ }^{-14} \mathrm{C}-$ glycine from the Radiochemical Center.

\section{Results and Discussion}

The production of kasugamycin, and the change of $\mathrm{pH}$ and residual sugar in the cultured broth during the shaking culture are shown in Fig. 1. The residual sugar in the broth starts to decrease rapidly after 1 day of the shaking culture

Fig. 1. Time-course of kasugamycin production

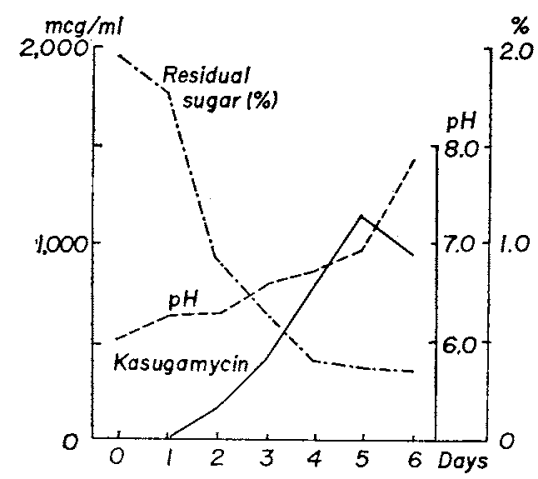

and this rapid decrease continues up to 3 days of the shaking culture. The residual sugar after 3 days is about $0.6 \%$ and that after $4 \sim 6$ days is about $0.4 \%$. The rapid production phase of kasugamycin is observed during 3 5 days after the start of the shaking culture. This production phase and the change of the residual sugar indicates the proper time for the addition of labelled compounds as 70 90 hours of the shaking culture. Therefore, labelled compounds were added at $70 \sim 90$ hours of the shaking culture and 15 24 hours thereafter the shaking culture was stopped. Kasugamycin was isolated and crystallized by the aid of the addition of cold kasugamycin. The amount of ${ }^{14} \mathrm{C}$-kasugamycin before addition of cold kasugamycin was determined by the disc method. The total radioactivity of ${ }^{14} \mathrm{C}$-kasugamycin gave the incorporation of labelled compounds into kasugamycin during the shaking culture. The results are indicated in Table 1 .

The extent of incorporation was about 5 times higher the $\mathrm{U}-{ }^{14} \mathrm{C}-\mathrm{glucose}$ or $\mathrm{U}-{ }^{14} \mathrm{C}-$ mannose than with $\mathrm{U}-{ }^{14} \mathrm{C}-$ maltose. However, when $\mathrm{U}^{-14} \mathrm{C}-$ maltose or $\mathrm{U}^{1{ }^{14}} \mathrm{C}-\mathrm{glucose}$ was added at the start of the shaking culture, much higher incorporation was obtained with maltose, and therefore, maltose is concluded to be a more suitable carbon source for the production of kasugamycin than glucose. The results here 
Table 1. Incorporation of ${ }^{14} \mathrm{C}$-compounds into kasugamycin

\begin{tabular}{|c|c|c|c|c|c|c|}
\hline \multirow{2}{*}{$\mathrm{C}^{14}-$ Compound } & \multirow{2}{*}{$\begin{array}{c}\text { Sp. act. of } \\
{ }^{14} \mathrm{C} \text {-compound } \\
(\mathrm{mc} / \mathrm{mm})\end{array}$} & \multirow{2}{*}{$\begin{array}{c}\text { Amount of } \\
{ }^{14} \mathrm{C} \text { added } \\
(\mu \mathrm{c}) *\end{array}$} & \multicolumn{3}{|c|}{ Kasugamycin recovered } & \multirow{2}{*}{$\begin{array}{l}\text { Incorp. } \\
\text { rate (\%) }\end{array}$} \\
\hline & & & $\begin{array}{c}\text { Amount } \\
(\mu \text { moles })\end{array}$ & $\begin{array}{c}\text { Sp.act.** } \\
\left(\times 10^{3} \mathrm{cpm} / \mathrm{M}\right)\end{array}$ & $\begin{array}{c}\text { Total act. } \\
\left(\times 10^{5} \mathrm{cpm}\right)\end{array}$ & \\
\hline U_ ${ }^{14} \mathrm{C}-$ Maltose & 5.9 & 25.6 & 97.5 & 5.51 & 5.37 & 1.91 \\
\hline U-14C-Glucose & 5.0 & $\begin{array}{r}10.0 \\
10.0 \\
10.0 \\
25.0 \\
166.7\end{array}$ & $\begin{array}{r}174.7 \\
200.9 \\
129.0 \\
81.3 \\
370.3\end{array}$ & $\begin{array}{r}6.87 \\
4.62 \\
6.74 \\
36.15 \\
58.15\end{array}$ & $\begin{array}{r}12.0 \\
9.28 \\
8.70 \\
29.39 \\
215.33\end{array}$ & $\begin{array}{r}10.72 \\
8.44 \\
7.91 \\
10.69 \\
11.75\end{array}$ \\
\hline U- ${ }^{14} \mathrm{C}-$ Mannose & 4.9 & 10.0 & 179.7 & 6.14 & 11.03 & 10.03 \\
\hline U-14C-Ribose & 3.8 & 11.3 & - & - & $* * * 4.40$ & 3.53 \\
\hline 1-14C-Glycerol & 4.7 & 7.5 & 134.3 & 0.81 & 1.16 & 1.41 \\
\hline U- ${ }^{14} \mathrm{C}-\mathrm{Py}$ ruvate & 6.5 & 10.0 & 145.4 & 0.97 & 1. 41 & 1.28 \\
\hline $1-{ }^{14} \mathrm{C}-$ Acetate & 10.0 & $\begin{array}{r}6.3 \\
31.5\end{array}$ & $\begin{array}{l}139.9 \\
160.8\end{array}$ & $\begin{array}{l}0.06 \\
0.40\end{array}$ & $\begin{array}{l}0.09 \\
0.64\end{array}$ & $\begin{array}{l}0.13 \\
0.18\end{array}$ \\
\hline U-14C-Myoinositol & 36.0 & $\begin{array}{r}6.0 \\
12.0\end{array}$ & $\begin{array}{l}108.3 \\
124.7\end{array}$ & $\begin{array}{l}36.74 \\
87.68\end{array}$ & $\begin{array}{r}39.79 \\
109.34\end{array}$ & $\begin{array}{l}60.29 \\
82.83\end{array}$ \\
\hline $1-{ }^{14} \mathrm{C}-$-Glycine & 7.9 & $\begin{array}{l}10.0 \\
25.0\end{array}$ & $\begin{array}{r}48.4 \\
105.5\end{array}$ & $\begin{array}{l}38.22 \\
48.27\end{array}$ & $\begin{array}{r}* * 18.50 \\
50.92\end{array}$ & $\begin{array}{l}17.29 \\
18.52\end{array}$ \\
\hline $2{ }^{14} \mathrm{C}-$ Glycine & 8.0 & $\begin{array}{r}5.0 \\
10.0\end{array}$ & $\begin{array}{r}62.2 \\
108.3\end{array}$ & $\begin{array}{l}21.06 \\
22.74\end{array}$ & $\begin{array}{l}13.10 \\
24.63\end{array}$ & $\begin{array}{l}23.82 \\
22.39\end{array}$ \\
\hline $\mathrm{U}-{ }^{14} \mathrm{C}-\mathrm{Glycine}$ & 10.2 & 500.0 & 196.3 & 364.75 & 716.0 & 13.02 \\
\hline
\end{tabular}

* by liquid scintillation counter

**** at the stage of $\mathrm{XE}-100$ eluate

obtained indicate that during the production phase glucose is more rapidly incorporated into kasugamycin than maltose. It is thought that the results are useful to devise a system of feeding material during the production to give increased yields of kasugamycin.

$\mathrm{U}-{ }^{14} \mathrm{C}$-myoinositol was incorporated to a very high degree, 60 or $82 \%$, and both ${ }^{1-14} \mathrm{C}$-glycine and $2^{2-14} \mathrm{C}$-glycine were also highly incorporated. As described in following papers ${ }^{9,10)}$, myoinositol is incorporated into the D-inositol moiety and glycine into the side chain.

${ }^{14} \mathrm{C}-\mathrm{K}$ asugamycin was hydrolyzed to $\mathrm{D}$-inositol by heating in $6 \mathrm{~N} \mathrm{HCl}$ and to kasuganobiosamine by heating in $\mathrm{Ba}(\mathrm{OH})_{2}$ solution. From the specific activities of $\mathrm{D}$-inositol and kasuganobiosamine, the specific activity of kasugamine was calculated. The specific acitivities of kasugamycin and kasugamine are indicated in Table 2. Glucose, mannose and maltose were incorporated more into the kasugamine moiety than into the residual moieties. Pyruvate and acetate appeared to a great extent in kasugamine moiety than the residual moieties. $\quad{ }^{1-14} \mathrm{C}-\mathrm{Glycerol}$ was taken equally in the kasugamine moiety and the residual moieties, though the total incorporation into kasugamycin was about 5 7 times lower than glucose as shown in Table 2. If glucose or glycerol is added at the start of the shaking culture, glycerol gives a much higher yield of kasugamycin, especially when it is cultured on a rotary shaking machine which gives higher aeration than a reciprocal shaking machine. It may be said that utilization of glycerol is balanced to produce the three moieties of kasugamycin. It is natural that myoinositol and glycine, which are utilized for formation of $\mathrm{D}$ mositol and the side chain respectively, are not taken into the kasugamine moiety. 
Table 2. Distribution of ${ }^{14} \mathrm{C}$ in the kasugamine part of kasugamycin

\begin{tabular}{|c|c|c|c|c|c|c|}
\hline \multirow{2}{*}{${ }^{14} \mathrm{C}-$ Compound } & \multirow{2}{*}{$\begin{array}{c}{ }^{14} \mathrm{C} \text { added } \\
(\mu \mathrm{c})\end{array}$} & \multirow{2}{*}{$\begin{array}{l}\text { Incorp. } \\
\text { rate into } \\
\text { kasugamycin }\end{array}$} & \multirow{2}{*}{$\begin{array}{c}\text { Sp. act. of } \\
\text { kasugamycin } \\
\left(\times 10^{3} \mathrm{cpm} / \mu \mathrm{M}\right)\end{array}$} & \multicolumn{2}{|c|}{ Sp. act. $/ \mu \mathrm{M}$ of $\mathrm{C}$} & \multirow{2}{*}{$\begin{array}{c}\text { Relative* } \\
\text { incorp. of } \\
\text { kasugamine }\end{array}$} \\
\hline & & & & Kasugamycin & Kasugamine & \\
\hline U-14C-Maltose & 25.6 & $1.91^{\%}$ & 5.51 & $394^{\mathrm{cpm}}$ & $687^{\mathrm{cpm}}$ & 1.74 \\
\hline U-14C-Glucose & 25.0 & 10.69 & 36.15 & 2,582 & 4,522 & 1.75 \\
\hline U-14C-Mannose & 10.0 & 10.03 & 6.14 & 439 & 805 & 1.83 \\
\hline 1 - $^{14} \mathrm{C}-$ Glycerol & 7.5 & 1.41 & 0.96 & 57.9 & 59.8 & 1.03 \\
\hline U-14C-Pyruvate & 10.0 & 1.28 & 0.97 & 69.3 & 104.5 & 1.51 \\
\hline $1-{ }^{14} \mathrm{C}-$ Acetate & 6.3 & 0.13 & 0.06 & 4.3 & 6.7 & 1.56 \\
\hline U-14 C-Myoinositol & 6.0 & 60.29 & 36.74 & 2,624 & 274 & 0.10 \\
\hline $1-{ }^{14} \mathrm{C}-$ Glycine & 25.0 & 18.52 & 48.27 & 3,448 & 23 & 0.007 \\
\hline $2-^{14} \mathrm{C}-$ Glycine & 10.0 & 22.39 & 22.74 & 1,624 & 8 & 0.005 \\
\hline
\end{tabular}

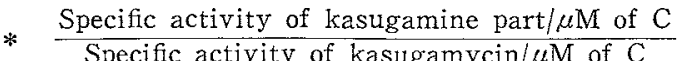

Deoxysugars such as colitose, abequose, paratose, tyvelose, and ascarylose have been isolated from bacteria and eggs of ascaris. These deoxysugars are known to be synthesized from glucose through nucleotide glucose. Tyvelose is 3,6-dideoxy-Dmannose. A.D. ELBEIN ${ }^{12)}$ reported that tyvelose is synthesized from glucose, through CDP derivatives (CDP-glucose $\rightarrow$ CDP-4-keto-6-deoxy-glucose $\rightarrow$ CDP-tyvelose). The intermediate which has two carbonyl groups is interesting, because the amination of its intermediate would give kasugamine.

\section{References}

1) Suhara, Y.; K. Maeda \& H. Umezawa: Chemical studies on kasugamycin. I. Acid degradation. J. Antibiotics, Ser. A 18(4) : 182 183, July 1965.

2) Suhara, Y.; K. MAEDA, H. UmezaWA \& M. OhNo: Chemical studies on kasugamycin. II. The structure of methylkasugaminide. J. Antibiotics, Ser. A 18(4) : 184 186, July 1965.

3) Suhara, Y.; K. MAeda \& H. UMezAWA : Chemimal studies on kasugamycin. III. Structures of kasuganobiosamine and kasugamycinic acid. J. Antibiotics, Ser. A 18(4): 187 190, July 1965.

4) Suhara, Y.; K. MaEda, H. Umezawa \& M. Ohno : Chemical studies on kasugamycin. IV. Synthetic transformations of kasuganobiosamine to kasugamycinic acid, isokasugamycinic acid, and their amides. J. Antibiotics, Ser. A 18(6):267 268, Nov. 1965.

5) Suhara, Y.; K. Maeda, H. Umezawa \& M. Ohno: Chemical studies on kasugamycin. V. The structure of kasugamycin. Tetrahedron Letters No. $12: 1239 \sim 1244,1966$.

6) IKEKAWA, T.; H. UMEZAWA \& Y. ITTAKA: The structure of kasugamycin hydrobromide by X-ray crystallographic analysis. J. Antibiotics, Ser. A 19(1) : 49 50, Jan. 1966.

7) Majumdar, S. K. \& H.J. Kutzener : Myoinositol in the byosynthesis of streptomycin by Streptomyces griseus. Science 135(3505) : 734, Mar. 2, 1962.

8) Rinehart, K. L., Jr. : Chemical and biosynthetic studies of neomycins and related antibiotics. I.A.M. Symposia on Microbiology, No. 6, Chemistry of Microbial Products pp. 48 71, Apr. 1964.

9) Fukagawa, Y.; T. Sawa, T. Takeuchi \& H. Umezawa: Studies on biosynthesis of kasugamycin. II. Biosynthesis of the amidine carboxylic acid moiety of kasugamycin. J. Antibiotics (in press)

10) Fukagawa, Y.; T. Sawa, I. Honma, T. Takeuchi \& H. Umezawa : Studies on biosynthesis of kasugamycin. III. Biosynthesis of the D-inositol moiety of kasugamycin. J. Antibiotics. (in press)

11) Hamada, M.; T. Hashimoto, T. Takahashi, M. Yokoyama, M. Mryake, T. Takeuchi, Y. Oкаmi \& H. Umezawa: Antimicrobial activity of kasugamycin. J. Antibiotics, Ser. A 18 (2) : 104 106, Mar. 1965 .

12) Elbein, A.D. : The enzymatic synthesis of cytidine diphosphate tyvelose Proc. Nat. Acad. Sci. 53(4) : 803 806, Apr. 1965. 